\title{
What are we missing here? Problematising wisdoms on teaching quality and professionalism in higher education
}

\author{
Schuck, S. ${ }^{\mathrm{a}}$, Gordon, S. ${ }^{\mathrm{b}} \&$ Buchanan, J. \\ ${ }^{\mathrm{a}}$ University of Technology Sydney, ${ }^{\mathrm{b}}$ The University of Sydney
}

\begin{abstract}
In this discussion paper we seek to challenge prevailing wisdoms in higher education regarding the value of measuring teaching quality, prescribing standards for professionalism and using student satisfaction as an indicator of teaching effectiveness. Drawing on the literature, we explore and probe four wisdoms in an attempt to identify and problematise popular assumptions about teaching and professionalism. We suggest that externalising procedures for assessing quality can be counter-productive to effective teaching and learning and propose core values we see as central to enhancing higher education practice: collegial reflection on practice, consideration of ethical issues and risk-taking.
\end{abstract}

Keywords: measuring teaching quality; accountability; professionalism; student evaluations 


\section{What are we missing here? Problematising wisdoms on teaching quality and professionalism in higher education}

\section{Introduction}

Education has become increasingly commodified in recent times. Indeed, the very ascription of the word 'quality' to education connotes a product or commodity rather than a process. In this paper we set out to deconstruct, and perhaps reconstruct, some of the prevailing 'wisdoms' about teaching quality and professionalism in higher education. In this process we examine assumptions on the meaning of student learning and teaching and reflect on central questions about the nature of education.

The debates that arise in higher education about teaching quality and professionalism are not new ones. Teaching as a central factor in improving learning has moved in and out of discussions on learning over the years. In the 1960s, studies in the area reflected the dominant theory of behaviourism and the external interest in accountability, and focused on different teacher competencies (Korthagen, 2004). In more recent times, notes Korthagen (2004), the focus of research on learning has changed. Research studies moved away from process-product studies that attempted to match overt teaching behaviours with learning outcomes, towards an emphasis on the 'self' or professional identity of the teacher. The value of multiple perspectives and the importance of beliefs were acknowledged, as was the complexity of teaching and learning (Korthagen, 2004). Discussion of the importance of teaching was replaced by the centrality of the student learning experience (Barr \& Tagg, 1995). The teacher's role was transformed from 'instructor' to 'guide', 'facilitator' or 'mediator' (Gordon \& Fittler, 2004). In the last few years, history is repeating itself (Korthagen, 2004): greater accountability, budgetary constraints and devaluing of the teaching profession has led to an educational climate in which teaching is defined through lists of behaviours, standards and measures and the intangible aspects of effective teaching are largely ignored (Rodgers \& Raider-Roth, 2006). Checklists and easy-to-digest numbers are used to describe both teaching quality and professionalism and the complexity of both concepts is negated (Johnson, 2000). We challenge the assumptions underlying these cut-rate notions of teaching quality and professionalism and propose arguments that problematise prevailing wisdoms about these concepts.

\section{Wisdom 1: Measuring teaching quality improves student learning}

There is debate in the literature as to whether measuring teaching quality does improve student learning. In the school context, Kleinhenz and Ingvarson (2004) argue that the strong connection between teaching quality and student learning outcomes makes the need for effective systems of teacher accountability essential. Ramsden (1991) contends that it is unduly pessimistic to suggest that teaching quality is extremely elusive and, therefore, difficult to measure. He goes on to say that it is possible to measure teacher quality accurately. Further, he suggests that good quality teaching is indicated by student satisfaction. Implicit in this argument is the link between student satisfaction and student learning.

In problematising the above argument, we note the potential for debilitation that current processes can have on teacher morale (Moore \& Kuol, 2005) and join others, including Leckey and Neill (2001) and Morley (2003a), in questioning two claims: that measuring teaching quality improves student learning, and that student 
satisfaction indicates teaching quality. We present our case for the first point immediately below and discuss the second one further in the paper. We start by asking: What is meant by student learning?

Student learning can include students' factual knowledge, students' critical analytic skills, or students' engagement in the topic (Halpern \& Riggio, 2003; Kuh, 2001). It depends on whose perspective is taken. Further, even if the academic world and all stakeholders were agreed on the nature of student learning and the role of the teacher, the question still arises: What is the aim of measuring teaching quality? If it is to improve teaching and hence student learning, why are such measures used by others than the teacher for whom this information might be valuable? What evidence is there that management use of the student satisfaction survey, in particular, as the primary indicator of teaching quality, is improving student learning? We propose with others (Johnson, 2000; Zabaleta, 2007) that a host of more complex indicators of teaching quality are ignored because they are not as easily digested for bureaucratic purposes, nor so convenient for marketing purposes and external dissemination.

Even if we were to accept that such uni-dimensional measures as those indicated by surveys give us valuable information, how are they actually measuring teaching quality? Student satisfaction surveys encourage us to teach for acquiescence. Yet, if part of our role as teachers is to disrupt existing viewpoints, that is, to preclude compliance on the part of our learners, why do we embrace it in our evaluation of our teaching? Why is such compliance regarded as an indicator of quality teaching? Indeed, McGettrick (2005, p.5) asserts that: "universities are not at their best when they have become places of compliance, conformity and adherence to regulation and edict. This is the antithesis of the open, creative and innovative environments that are the dream of the liberal educator and creative teacher".

The only data from student feedback questionnaires that are aggregated in Australia are a series of Likert scale responses. Perhaps by necessity, the questions embedded in these surveys are what could be called 'evaluation lite', in that they consist of vastly pared down representations - and arguably misrepresentations - of quality teaching and learning. One question asks if the subject's delivery was consistent with its stated aims. A student's ability to answer this question in a meaningful way rests on the assumption that the student has a clear recollection and understanding of the subject's stated aims at the time they are responding to the questionnaire. The questionnaire does not appear to elicit students' perceptions of stated and actual outcomes in a broader context of perceived relevance to their studies and subsequent vocational expectations.

Part of the answer as to why the student feedback questionnaire is a privileged measure in Australia, at least, may be that these questionnaire responses inform individual and institutional league tables and funding formulae. Systems of quality assurance have long been endorsed in government and institutional policy statements in higher education and measuring teaching quality as a mechanism to improve accountability to stakeholders is extolled in debate on education in the public sector (Department of Education Science and Training (DEST), 2007).

A package of reforms of higher education, legislated in 2003 in Australia, characterised reforming quality as: "incentives to improve performance and greater accountability" (DEST, 2007, p.1). We question whether measuring teaching quality in the ways described here provides incentives to teachers. Rather, we suggest that this process might quench teachers' zeal for promoting critical thinkers. Further, as Harvey (2003, p. 4) highlights, it is more important to ensure an appropriate "action cycle" for using data to enhance student learning than it is to have in place 
mechanisms for collecting data. Feedback from student questionnaires at the module level provides little information about what would improve the learning situation. It tends to inhibit qualitative discussion and rarely benefits the students who provide the feedback (Harvey, 2003). An empirical investigation by Kember, Leung and Kwan, (2002) led to a concurring conclusion: there was no evidence that the use of student feedback questionnaires contributed to improved teaching quality, at least as perceived by the students.

Gibbs and Habeshaw (2003) distinguish between schemes for promoting quality teaching that are celebratory and those that are orienting. They propose that traditional schemes "tend to look backwards" (p.29), seeking to find and reward teachers who have excelled in the past, with perhaps no expectation of future contributions to their institutions. In contrast, recently developed schemes are more likely to attempt to orient teachers to the future development of teaching. Teachers are rewarded for their willingness "to put extra effort into changes of the kind the institution is prepared to support" (p.29). Hence whether an institution looks backward or forward is critical in determining what they mean by teaching quality and how it is measured. Bass (1999) suggests that instead of viewing problems in teaching as issues needing quick solutions, we develop the scholarship of teaching by investigating those problems over a longer period of time, much as we investigate research problematics. This suggestion promotes looking forward and is supportive of moves to enhance teaching quality rather than merely measure it for the purpose of reward or retribution.

For us, the major questions that arise here concern what we mean by teaching quality (Schuck, 2006) and the ways we measure such quality. Data about students' perceptions of teaching can be obtained from journal entries and qualitative student feedback. These provide more depth than subject evaluation surveys but are based on a matching assumption - that student perceptions are good indicators of student learning. However, students often hold fairly restricted models of learning on entering university, based on their prior learning experiences (Honkimäki, Tynjälä \& Valkonen, 2004). A different measure of teaching quality is student success in attaining the subject learning outcomes. In this case, the question arises as to how those learning outcomes are determined in the first place. Do desirable learning outcomes encompass those which best prepare our students for their future careers, evoke a sense of curiosity and a desire to learn more in that subject area and encourage critical and reflective thinking and analysis? Or are there different criteria? Further, how do we assess if learning outcomes have been achieved? Student results in assessment items are usually used to determine whether learning outcomes have been achieved. However, assessment items will, at best, only measure what the teacher views as important to assess. As a result, such an assessment system can be self-fulfilling. We ask again, whose view prevails and whose vision of future requirements dominates?

The assertion that measuring teaching quality improves teaching suggests that improving teaching quality is mainly about enhanced scores on extrinsic measures - a view of accountability that seems to work against notions of professionalism. And so we lead into our argument against a second wisdom.

\section{Wisdom 2: Accountability improves professionalism}

We have suggested above that the process of measuring teaching quality could lead to practices that do not enhance teaching quality, even as they promote accountability. We contend, too, that professionalism does not align with accountability through 
measurement.

Perhaps it is most useful at this point, to review definitions of professionalism and ideas about it. A consultative paper on professionalism (Universities UK et al., 2004, p. 1) defines professionalism as follows:

\begin{abstract}
'Professionalism' is commonly understood as an individual's adherence to a set of standards, code of conduct or collection of qualities that characterise accepted practice within a particular area of activity.
\end{abstract}

McGettrick, in response to this paper (2005) suggests that this definition is limited. We ask too: where do the pioneers fit, the courageous academics who push the barriers of accepted practice? Indeed, McGettrick (2005, pp. 4,5) underlines this point by suggesting the following definition of a profession.

\begin{abstract}
One definition of a profession might be that it is a group of people entrusted by the public to work with dangerous modalities in the common good. This raises some interesting and unusual features of a profession. In what ways is a teacher 'working with dangerous modalities'?.... If a teacher is concerned with the sensitive and even contentious issues of values and ideals of students, what could be more dangerous in the hands of people who have ulterior motives than working with truth, with positive social values, and with the thoughts of future leaders in society?
\end{abstract}

Bottery and Wright (1997) add that key criteria for professionalism are autonomy and expertise. These are circumscribed by management agendas in which teachers are accountable for policy implementation but excluded from policy determination or participation - there is "devolution of responsibility but not power" (Bottery and Wright, 1997, p. 9). If a teacher is undergoing an exercise in external measurement, then it is not professionalism that is ensured but compliance.

Moreover, as Johnson (2000, p. 424) points out: "the concept of "professional development' is reduced to a process of receiving and reacting to summative measures, where the measures are treated as facts, not questions, and are assumed sufficiently meaningful and informative on face value". Hence the concept of 'good teaching', becomes closed: "the professional lecturer is not required to draw on or develop a questioning, reflective attitude towards the idea of teaching" (Johnson, 2000, p. 424).

The above discussion suggests that the alignment of accountability and professionalism is problematic. Accountability appears to mean the ability to justify and account for our actions to an external person, agency or institution (DEST, 2002). Professionalism denotes the ability to take responsibility for our own actions- to make decisions and judgments based on sound thinking, reflection and knowledge of the context in which we are operating. Hence are we not placed in a contradictory situation when we suggest that accountability improves professionalism?

We argue for a view of professional practice that enables teachers to look independently or collaboratively at their own practices and ways of enhancing teaching, rather than placing the evaluation of the practice outside the teacher's domain, as an externally driven activity in which the teacher has little agency, and may even be an unwilling actor. We concur with McGettrick (2005) that such an internal accountability aligns with a core aim for higher educators-being professionally responsible.

The next questions then arise. How is professionalism characterised and what issues does this raise? We challenge a prevailing view about professionalism. 


\title{
Wisdom 3: Professionalism is defined by a set of standards concerning practices, knowledge and values
}

Criteria and frameworks for professional standards are considered essential in many countries to enable higher education institutions to gain accreditation and to support the professional development of staff. In Australia there has been a call for "agreed standards of professional practice and the ways in which attainment of these standards of professional practice can be validated and recognised publicly" (DEST, 2002, p.1). Similarly, in the UK, the National Professional Standards Framework records one of its aims as "demonstrating to students and other stakeholders the professionalism that staff bring to the support of the student learning experience" (Higher Education Academy, 2006, p.1).

The National Professional Standards Framework outlines areas of activity concerning planning, teaching and assessment, scholarship and research and professional development, as well as "core knowledge", including knowledge of the subject material, understanding of how students learn and methods for evaluating the effectiveness of teaching. Professional values are given prominence in the Framework and are summarised as (Higher Education Academy, 2006, p.3):

1. Respect for individual learners

2. Commitment to incorporating the process and outcomes of relevant research, scholarship and/or professional practice

3. Commitment to development of learning communities

4. Commitment to encouraging participation in higher education, acknowledging diversity and promoting equality of opportunity

5. Commitment to continuing professional development and evaluation of practice.

Such activities, knowledge and values appear indisputable measures of professionalism. Yet the implication of such a framework is that standards for professionalism in higher education can be set out independently of the dynamic and lived-in experiences and situations of teachers, their cultures and beliefs and those of their students. We ask whether professionalism excludes self-doubt, questioning and reconceptualising our roles as teachers. Moreover, what is the evidence that the application of such standards does improve student learning? More fundamentally, what do terms such as 'acknowledging diversity' and 'learning communities' mean in practice? And to what extent do student feedback questionnaires and league tabling realise the above five ends for communities of learner-teachers.

We ask, too, whether professionalism implies control over all aspects of teachingin which case we are lost. As the members of the Staff and Educational Development Association (SEDA) in the UK concur:

\begin{abstract}
We rarely have complete control over the environment in which we develop or support learning. This environment not only includes the physical or virtual space but also the content, structure and assessment scheme of any activity or programme on which we work. We also need to work within the relevant departmental, institutional or national frameworks" (SEDA, 2005, pp. 4, 5).
\end{abstract}

Adding another dimension to ideas about control, Hamachek (1999) suggests that conscious control over our actions and goals is only part of the story. "Consciously, we teach what we know; unconsciously we teach who we are" (p. 209). Teacher identity itself is contextual and emerges through experience and participation in specific, cultural activities (Gordon \& Fittler, 2004). As well, the subconsciousness of our teaching is influential, "how we teach IS the message" (Russell, 1997, p. 32).

Rather than define and characterise professionalism as de-contextualised and 
universal, we suggest considering ethical practice as encompassing professionalism. Ethical considerations are intrinsically contextual - they have to do with relationships in specific contexts. Hence ethical practice, in the first case, means reflecting on and revising the assumptions that underpin our teaching. As proposed by SEDA (2005, p.2):

Professionalism embraces scholarship and ethical practice. In addition, it involves establishing and maintaining clear contracts or frameworks with those whose learning is to be supported. It also encourages us to commit to the ongoing improvement of our own practice.

Elbaz (1992) reminds us, too, that in trying to improve student learning there is a danger that we view what students do only in the present and as an indicator on a path to an objective and that the value of students' learning beyond current 'performance' is forgotten.

A teacher has an ethical function and responsibility to ask what students learn, in what context and with what goals "and to reflect on who has the opportunity to learn what" (Renshaw, 2003, p. 358, italics in original). Elaborating, Glazier (2005, p. 231) suggests that teachers' "subject positions, as raced, classed, and gendered", among others, affect how students and colleagues view teachers and impact on actions and discourses in their teaching contexts. Teachers' failure to reflect on implicit assumptions about their positions and those of others, could, albeit inadvertently, lead to privileging the experiences of perceived like-minded students over those whose discourses suggest differences. Elbaz (1992) concurs, suggesting that an attitude of watchful attentiveness is a moral dimension of teacher knowledge and concerns more than watching over the students in one's charge; it is also watching over oneself and colleagues at the same time and with the same attentive concern. So, ethical practice includes being attentive to one's own feelings and situations, as experienced and embodied, as well as those of students. This could include attending to dissonanceexpressions of fear, vulnerability, and anger (Elbaz-Luwisch, 2004).

The professional values outlined in the National Professional Standards Framework (Higher Education Academy, 2006) are in accord with expressions of ethical principles and commitments. However, the sense conveyed by these standards is that such values can be absorbed from external sources and that following the guidelines is unproblematic for an educator--(s)he simply rises above any context and conflict of interest. We suggest, on the contrary, that reflection on ethics is essentially prone to controversy, diverse points of view and tensions. For example, in value 1 of the Framework: respecting the individual learner-there is an assumption that learners will respect each other-and this is not always the case. Open and collaborative interaction with colleagues is another seemingly straightforward principle of professionalism which, on reflection, is far from clear cut. What if a colleague's behaviour is not in the best interest of a student or students or there is a clash of interest between colleagues or between a staff member and institutional policy? (See Campbell, 2005, for an exposition.)

We suggest that issues of ethical practice play out at three levels in higher education:

- Teacher ethical practices, in determining what individual teachers teach, how they teach, how they will assess learning and evaluate teaching, and whom they will consider in developing their curriculum and approaches.

- Institutional ethical practices, in determining what aspects of teaching are encouraged, ignored or promoted, and in determining class sizes and modes of teaching; 
- Teacher professional communities, in determining their collective responsibility, and the codes of ethical practice for their community.

Hence we concur with Campbell (2005) that there is a need for debate about tensions between the role of the teacher as a moral person and a "moral educator, as embodying professional moral agency" (p. 208).

Our next wisdom concerns who should have the last word on teaching quality - are students as 'consumers' of education the best judges of its quality?

\title{
Wisdom 4: Students' views of education accurately capture the essence of good teaching
}

There is an entrenched dilemma in teaching. Virtually everyone in developed nations has been subjected to schooling (if not education), so almost everyone nurses an opinion on what good schooling should look and feel like. This begs the question as to whose image of good or great teaching is to be the yardstick. To whose image are we to conform?

We will lead with a claim. By definition, a teacher is more learned than her or his students. If this is the case, then the pedagogical knowledge, experience and expertise of a teacher is greater than the corresponding means of each of these capacities of any of their given classes of students - presuming that capacities such as learner expertise can be quantified and reduced to a mean.

We ask further: What is student satisfaction? As the Centre for Higher Education Research and Information (CHERI, 2003, p 26) observes:

\begin{abstract}
One fundamental difficulty with this approach [measuring teacher quality based on student satisfaction] is that it privileges satisfaction as a notion that is coherent, homogeneous and unproblematic. In fact, the limited amount of research on this topic suggests that student satisfaction is a complex yet poorly articulated notion that is influenced by a wide variety of contextual factors which are not intrinsically related to the quality of teaching.
\end{abstract}

Empirical research supports the above observation, showing that student satisfaction responses may be influenced by diverse, extraneous factors, including age of instructor, low grades and even the time at which classes are held (Zabaleta, 2007). Other variables in the mix are likely to include assessment type, class size, how challenging a topic is and a class culture of (un)appreciativeness.

A study by Shevlin et al. (2000) suggests that students approach the evaluation of teaching on the basis of a global factor underpinning a host of lecturer features - and this factor is lecturer charisma. Hence a primary issue of concern is the validity of the evaluation instrument and this issue challenges the use and "fairness" of student evaluations in decision-making (Shevlin et al., 2000, p. 403). One "shocking" finding (Zabaleta, 2007, p. 64) based on over 18,000 student evaluations of a language program in San Diego was that teachers with one year of experience or less received higher evaluations than experienced teachers.

There are other arguments for nurturing a healthy mistrust of student responses. A 'consumer-driven' regimen is likely to inhibit experimentation on the part of the higher education teacher, impelling them to regress to 'tried-and-true' modes of teaching and assessing. The problem is compounded for education students. They appear to expect and reward clear-cut strategies and solutions from their educators; at least some students are asking why their teacher educators are devoting so much time to seeking feedback on 'performance' if these same teachers purport to be experts (te Riele \& Pressick-Kilborn, 2006). But does providing student teachers with such 
strategies, largely to please them, portray a false construct of the messy nature of learning and teaching? As Buchanan (2006, p. 141) observes: "teaching does not consist of prepackaged microwaveable solutions"-for learners or for teachers.

Together we need to identify and deconstruct the experiences we share and the learning in which we engage (Buchanan, 2006). Using students as critical friends in which their input at a deep level is encouraged is a valuable way of enhancing teaching - but it is not easily done. Filling in surveys or giving teachers a quick response about the class before moving on to the next class encourages superficial approaches (Harvey, 2003) to learning about learning and teaching; more time and discussion is needed to help students learn how to provide deeper and more thoughtful feedback to their teachers, and for students to develop metacognitive skills.

The CHERI report (2003) observes that student feedback is generally used for at least three purposes: to monitor the quality of teaching, improve it and advise students about it. The commodification of education is challenged by the CHERI Report (2003, p. 26) as follows:

\footnotetext{
It is, in any case, hard to justify the satisfaction of students as a fundamental goal of higher education in its own right, and to that extent higher education should not be likened to a commodity or service. This is not to argue that satisfaction ratings are wholly irrelevant to institutions (positive ratings may prove very useful for marketing purposes), simply that they are uninformative about issues of quality.
}

Zabaleta (2007, p. 67) sums up the view about student evaluations of teaching more bluntly, concluding that at best these evaluations are inaccurate, or indices of "consumer satisfaction". At worst they are a misuse and a way of bullying teachers. Similarly, Morley (2003b) questions the power discourses of such processes.

The final issue we bring to attention is the under-researched topic of the ownership of feedback data. Teachers may be less willing to act on the findings of feedback, and students may be more sceptical about the value of providing feedback, if this feedback seems divorced from the immediate context of teaching and learning. These reactions are very likely if student feedback is collected, analysed and published by an impersonal agency that is wholly external to their institution (Hodgson \& Whalley, 2006), but are arguably little ameliorated if conducted by the institution's central administration. The collection of feedback concerning programmes or institutions for quality assurance purposes does not reduce the need to obtain feedback concerning teachers or course units for developmental purposes. This is an important pointgetting feedback within our classes is much more of an incentive to change than the central survey with its deficiencies and potential for misuse.

\section{Conclusion}

Our discussion about teaching quality and professionalism has challenged prevailing wisdoms. We have also proposed different wisdoms that we hope will lead to other challenges and more discussion. To sum up, we believe that there is a need for a broader understanding of teaching quality and better ways of ascertaining such quality than use of student surveys; that an internal accountability leads to professional responsibility far more than an externally-driven requirement. We argue that professionalism must embrace more than a set of prescribed standards as unproblematic criteria for professionalism; it must incorporate ethical dimensions; and that student satisfaction is but one, limited, way of ascertaining teaching quality and professionalism.

Promotion of student learning is surely the goal and the measure of quality teaching. 
Roberts, Oakey and Hanstock (2007) discuss ways of instigating a supportive learning environment in their university. By linking policy and practice in teaching and learning more directly to research outcomes and operationalising a "generally more scholarly approach to learning and teaching", their university is developing a "virtuous circle" (Roberts et al., 2007, p. 300), thus enhancing students' learning experiences. Their case study aligns with Harvey's (2003, p. 4) "action cycle" for effective contribution to internal improvement processes: namely a regular and continuous cycle of analysis, reporting, action and feedback.

We join with Edwards (2002) who suggests that as professionals we develop relational agency - a capacity for joint working towards shared goals. Relational agency emphasises responsibility to the group and an enhanced sense of efficacy through drawing on the support and collective capabilities of others. This emphasis on collective responsibility enables teachers to undertake those responsive pedagogic actions that may involve a degree of risk. Edwards (2002, p.8) sees this as important: "the new knowledge economy is going to need practitioners who are confident risk takers able to support learners in the processes of knowledge production as well as knowledge use".

Finally we return to the (unanswered) question that sparked our writing: What is quality teaching? According to McGettrick (2005, p. 5), "Great teaching does not come from the application of prescriptive outcomes, but from the inspiration that characterises relationships and motivation for learning in the service of thought".

In so doing, both teachers and managers need to "relinquish control to gain influence" (Senese, 2002, p. 51) and increase the effectiveness of education. A scary, risky business, that.

\section{References}

Barr, R. B., \& Tagg, J. (1995) From teaching to learning: A new paradigm for undergraduate education, Change, 6(6), 12-25.

Bass, R. (1999) The scholarship of teaching: What's the problem? Inventio: Creative Thinking about Learning and Teaching, 1(1). Available online at:

http://www.doit.gmu.edu/Archives/feb98/randybass.htm (accessed 25 October 2006).

Bottery, M. \& Wright, N. (1997) Impoverishing a sense of professionalism, Educational Management \& Administration, 25(1), 7-24.

Buchanan, J. (2006) Splashing in puddles? What my teaching and research tell me about my teaching and research, in: P. Aubusson \& S. Schuck (Eds) Teacher learning and development: the mirror maze (Dordrecht, Springer), 131-144.

Campbell, E. (2005) Challenges in fostering ethical knowledge as professionalism within schools as teaching communities, Journal of Educational Change, 6, 207226.

Centre for Higher Education Research and Information, NOP Research Group \& SQW Ltd. (2003) Collecting and using student feedback on quality and standards of learning and teaching in HE [Report to Higher Education Funding Council for England by CHERI (Open University), NOP Research Group and SQW Ltd]. Available online at:

http://www.hefce.ac.uk/Pubs/rdreports/2003/rd08_03/ (accessed 6 October 2006).

Department of Education Science and Training (DEST) (2002) The role and impact of faculty development in teaching and learning in higher education (Canberrra, The Commonwealth of Australia). 
Department of Education Science and Training (DEST) (2007) Higher education summary. Available online at:

http://www.dest.gov.au/sectors/higher_education/higher_education_summary.htm (accessed 8 October 2007).

Edwards, A, (2002) Contriving the formation of professional minds: conflicting cultures in the preparation of beginning teachers. Paper presented at the Annual Meeting of the American Educational Research Association, 1-5 April, New Orleans. Available online at:

http://www.education.bham.ac.uk/research/csat/publications/aeraite1-aedwards.doc (accessed 6 November 2006).

Elbaz, F. (1992) Hope, attentiveness, and caring for difference: The moral voice in teaching, Teaching \& Teacher Education, 8(5), 421-432.

Elbaz-Luwisch, F. (2004) How is education possible when there's a body in the middle of the room? Curriculum Inquiry, 34(1), 9.

Gibbs, G. \& Habeshaw, T. (2003) Recognising and rewarding excellent teaching (2nd ed) (Milton Keynes, National Co-ordination Team for the Teaching Quality Enhancement Fund, Open University). Available online at:

http://www.heacademy.ac.uk/documents/GPGuide_RRET.pdf (accessed 31 October 2006).

Glazier, J. (2005) Talking and teaching through a positional lens: Recognizing what and who we privilege in our practice, Teaching Education, 16(3), 231-243.

Gordon, S. \& Fittler, K. (2004) Learning by teaching: A cultural historical perspective on a teacher's development, Outlines, 6(2), 35-46.

Halpern, D. \& Riggio, H. (2003) Thinking critically about critical thinking (4th ed) (Mahwah, NJ, Lawrence Erlbaum Associates).

Hamachek, D. (1999) Effective teachers: What they do, how they do it and the importance of self-knowledge, in: R.P. Lipka \& T.M. Brinthaupt (Eds) The role of self in teacher development (Albany, NY, State University of New York Press), $189-224$.

Harvey, L. (2003) Student feedback [1], Quality in Higher Education, 9(1), 3-20.

Higher Education Academy. (2006). The UK Professional Standards Framework for teaching and supporting learning in higher education. Available online at: http://www.heacademy.ac.uk/professionalstandards.htm (accessed 23 October 2006).

Hodgson, K \& Whalley, G. (2006) Quality, the enhancement of a university's teaching and learning and the role of quality officers, Teaching in Higher Education, 11(4), 509513.

Honkimäki, S., Tynjälä, P. \& Valkonen, S. (2004) University students' study orientations, learning experiences and study success in innovative courses, Studies in Higher Education, 29(4), 431 - 449.

Johnson, R. (2000) The authority of the student evaluation questionnaire, Teaching in Higher Education, 5(4), 419-434.

Kember, D., Leung, D. \& Kwan, K. (2002) Does the use of student feedback questionnaires improve the overall quality of teaching? Assessment \& Evaluation in Higher Education, 27(5), 412-425.

Kleinhenz, E. \&. Ingvarson, L.C. (2004) Teacher accountability in Australia: Current policies and practices and their relation to the improvement of teaching and learning, Research Papers in Education (UK), 19(1), 31-49. 
Korthagen, F. (2004) In search of the essence of a good teacher: Towards a more holistic approach in teacher education, Teaching and Teacher Education, 20, 7797.

Kuh, G. (2001). Assessing what really matters to student learning: Inside the national survey of student engagement, Change, 33(3), 10-17.

Leckey, J. \& Neill, N. (2001) Quantifying quality: the importance of student feedback, Quality in Higher Education, 7(1), 19-32.

McGettrick, B. (2005) Towards a framework of professional teaching standards [Discussion in Education Series]. Available online at: http://escalate.ac.uk/2044 (accessed 18 September 2006).

Moore, S. \& Kuol, N. (2005) Students evaluating teachers: exploring the importance of faculty reaction to feedback on teaching, Teaching in Higher Education, 10(1), 57-73.

Morley, L. (2003a) Quality and power in higher education (Buckingham, Open University Press.

Morley (2003b) Reconstructing students as consumers: power and assimilation? In: M. Slowey \& D. Watson (Eds) Higher education and the lifecourse (Buckingham, Open University Press), 79-92.

Ramsden, P. (1991) A performance indicator of teaching quality in higher education: The course experience questionnaire, Studies in Higher Education, 16 (2), 129151.

Renshaw. P. (2003) Community and learning: contradictions, dilemmas and prospects, Discourse: Studies in the Cultural Politics of Education, 24(3), 355-370.

Rodgers, C.R. \& Raider-Roth, M.B. (2006) Presence in teaching, Teachers and Teaching, 12(3), 265-287.

Roberts, C., Oakey, D. \& Hanstock, J. (2007) Developing a supportive environment for teaching and learning: A case study in a pre-1992 UK university, Journal of Higher Education Policy and Management, 29(3), 289-302.

Russell, T. (1997) Teaching teachers: How I teach IS the message, in: J. Loughran \& T. Russell (Eds) Teaching about teaching: Purpose, passion and pedagogy in teacher education (London, Falmer Press), 32-47.

Senese, J. (2002) Opposites attract: What I learned about being a classroom teacher by being a teacher educator, in: J. Loughran \& T. Russell (Eds) Improving teacher education practices through self-study (London, Routledge Falmer) 43-55.

Schuck, S. (2006) Evaluating and enhancing my teaching: What counts as evidence? In: P. Aubusson \& S. Schuck (Eds) Teacher learning and development: The mirror maze (Dordrecht, Springer), 209-220.

Shevlin, M., Banyard, P., Davies, M. \& Griffiths, M. (2000) The validity of student evaluation of teaching in higher education: Love me, love my lectures? Assessment \& Evaluation in Higher Education, 25(4), 397-405.

Staff and Educational Development Association. (2005) SEDA-PDF Values. Available online at: http://www.seda.ac.uk/pdf/11\%20SEDA\%20PDF-Values.htm (accessed 10 October 2006).

te Riele, K. \& Pressick-Kilborn, K. (2006) Learning from peer observation in teacher education. Paper presented in the symposium 'Self-study as collective and collaborative endeavour' at the Annual Meeting of the American Educational Research Association, San Francisco, 7-11 April.

Universities UK / SCOP / HEFCE / Higher Education Academy (2004) Towards a framework of professional teaching standards. Available online at:

http://www.universitiesuk.ac.uk/consultations/universitiesuk/downloads/teachingstan 
dards.pdf (accessed 22 September 2006).

Zabaleta, F. (2007) The use and misuse of student evaluations of teaching, Teaching in Higher Education, 12(1), 55-76. 